\title{
VRIJEME OTVORENOG ZNANJA
}

\section{Berislav Žarnić}

Filozofski fakultet,

Sveučilište u Splitu, Hrvatska

berislav@ffst.hr

U ovom je radu prepoznata i aksiomatski opisana minimalna teorija vremenskog poretka, koja je nazvana 'prostim vremenom'. Dodajući ili isključujući uvjete jedinstvenosti i sveobuhvatnosti, pokazali smo kako se prosto vrijeme može razviti u četiri tipa pojmova o vremenskom poretku. Za tri od četiri tipa pronašli smo primjere u povijesti ideja (Newton, Kant, Einstein) te tumačenjem relevantnih citata proveli tipološku klasifikaciju primjera (jaki temporalni monizam, slabi temporalni monizam, jaki temporalni pluralizam). Otkrili smo da se četvrti, nedostajući tip nalazi u dječjoj teoriji vremena (Piaget). U razvoju pojma vremena uočili smo da jedan element logičke strukture pojma vremena mijenja status: od definiranog, preko primitivnog, natrag $u$ status definiranog. Taj smo fenomen slobodno nazvali anomalijom jer se tu ruši kontinuitet logičke strukture u razvoju pojma. Taj uvid još jednom potvrđuje dinamični karakter znanja, ali sada ne samo na materijalnoj strani, nego i na formalnoj. Prema u ranijim radovima utvrđenom odnosu prirode znanja i cilja obrazovanja (Žarnić, 2001), anomaliju smo prepoznali kao razlog obrazovanju za otvorenost. Oslanjajući se na otkriće sistematizacijske snage pojma otvorenosti (Peters, 2010), skicirani su obrisi obrazovanja za otvorenost u odnosu na razvoj pojma vremena i prosvjetiteljsko razumijevanje obrazovanja.

Ključne riječi: logika vremena, obrazovanje za otvorenost, Jean Piaget, pojmovna promjena, tipologija vremenskih poredaka 


\section{Vrijeme kao otvoreni pojam*}

Da se pojam znanja odnosi na otvoren proces, poznato je u logici (Gödel), epistemologiji (Piaget) i filozofiji znanosti (Popper). Pojam humanističkog obrazovanja uključuje otvorenost prema razvoju raznolikih sposobnosti, od onih za logiku do onih za muziku (u krugu sedam slobodnih umijeća, lat. septem artes liberales), te brigu da se takav razvoj omogući. Obrazovanjem prosvjetiteljski filozofi nazivaju put prema otvorenosti duha. Svojstvo otvorenosti znanja nalazimo i na razini pojmova. Vrijeme je takav otvoren pojam. Otvoren, i s obzirom na sadržaj i s obzirom na svoju logičku strukturu.

Za svrhu istraživanja pojma vremena uvest ćemo četveročlanu tipologiju vremenskih poredaka. Primjere za tri tipa pronaći ćemo u povijesti ideja (kod Newtona, Kanta i Einsteina) te ćemo pokazati da je četvrti tip otkrio Piaget kao dječji pojam vremena. U procesu promjena tipova vremenskih pojmova uočavamo da se neki elementi odsutni iz jednog pojma ne javljaju ni kod posredno kasnijeg pojma iako ih ima u pojmu koji ova dva povezuje. Konkretno, istodobnost nema ulogu primitivnog pojma ili intuicije ni u dječjem pojmu o vremenu, koji nazivamo slabi temporalni monizam, kao ni u posredno kasnijem pojmu o vremenu u specijalnoj teoriji relativnosti, koji nazivamo jaki temporalni pluralizam. Istodobnost dobiva intuitivni ili primitivni položaj u Newtonovu pojmu vremena jednako kao u pučkom (tj. većini prihvatljivom) pojmu, koji svrstavamo pod jaki temporalni monizam. Jaki temporalni monizam dolazi u povijesnom redoslijedu nakon slabog temporalnog monizma, a prije jakog temporalnog pluralizma. Otkrivene činjenice pokazuju da promjene u poimanju vremena uključuju izmjenu logičkog statusa pojma o istodobnosti, koji sa statusa definiranog pojma prelazi na status intuitivnog pojma da bi se opet vratio početnom, neintuitivnom obliku.

Ova zanimljiva činjenica da promjene pojma uključuju promjene njegove logičke strukture omogućuje jasnije razumijevanje spoznajne

* Dijelovi ovoga rada bili su predstavljeni na plenarnom izlaganju na znanstvenom skupu Kompetencije suvremenog učitelja i odgojitelja: izazovi za promjene na Filozofskom fakultetu u Splitu 2012. te u okviru predavanja na Festivalu znanosti na Sveučilištu u Splitu 2013. i na javnoj tribini $O$ vremenu u suorganizaciji Prirodoslovno-matematičkog fakulteta i Filozofskog fakulteta u Splitu 2013. Zahvaljujem sudionicima spomenutih događanja na poticajnim pitanjima. Za akademsku komunikaciju vezanu uz ovaj tekst posebno sam zahvalan Gabrieli Bašić, Tonću Kokiću, Michaelu Petersu, Franji Sokoliću i Tomislavu Živkoviću. 
otvorenosti kao obrazovnog cilja. Spoznajna otvorenost uključuje otvorenost prema drukčijim sadržajima kao i otvorenost prema promjeni vlastitog načina mišljenja. Ove činjenice daju snažnu potporu znamenitom savjetu prvog hrvatskog pedagoškog znanstvenika Stjepana Basaričeka (1903) da se uloga učitelja ne može suziti na predavanje gotovih istina, nego učenika u prvome redu valja učiti misliti. Zaista, gotove istine o vremenu iz specijalne teorije relativnosti mogu se primiti samo ako se počne drukčije misliti.

\section{Tipovi vremenskih poredaka}

U ovom tekstu bavit ćemo se samo tipologijom teorija o vremenu za prirodne događaje i to s obzirom na vrstu poretka koji se u takvom vremenu uspostavlja. Sa strane ćemo ostaviti logička pitanja izražajnosti jezika o vremenu, kao i pitanja o smjeru vremena, o doživljaju trajanja, o diskretnosti ili kontinuiranosti vremena te mnoga druga.

\subsection{O čemu neće biti riječi}

Teorije vremena uključene su u skoro svim teorijama, a prešutno i u običnom jeziku u glagolskim vremenima. Teorije vremena u nekim disciplinama dobile su ekplicitni iskaz (na primjer, u fizici), dok su u nekima prešutno pretpostavljene (na primjer, u povijesnim znanostima).

U naše vrijeme u logičkim su istraživanjima vremena prepoznate i opisane neke od implicitnih teorija vremena. Takvih se implicitnih teorija ne možemo lišiti. Razgovaramo o nepovratnosti prošloga (1), o postojanju budućnosti (2), o mogućnostima (3), o neizvjesnoj budućnosti i nepromjenljivoj prošlosti (4) te o mnogim drugim svojstvima vremena. O različitim načinima razumijevanja vremena ovdje neće biti riječi. Sa stajališta ovog teksta svejedno je ima li vrijeme »otvorenu budućnost«, kao u primjerima (3) i (4), ili je ona zatvorena, kao u primjerima (7) i (8). Jednako tako, nećemo zauzimati stajalište o tome je li moguće »vraćanje istog « (5) ili nije (1), ima li kraja vremenu (6) ili nema (2), kao ni o mnogim drugim pitanjima iz metafizike vremena.

(1) Ča je bilo, tega više ni.

(2) Vezda bude da nekak vre bude.

(3) Moglo je biti drukčije sve. 
(4) Mnogi putovi vode u budućnost, samo jedan u prošlost.

(5) Ča je bilo, tega će još bit.

(6) Nekdar bude da nikak vre ne bude.

(7) Ništa nije moglo drukčije biti.

(8) Samo jedan put vodi u budućnost i samo jedan put u prošlost.

Također ćemo zanemariti logičko pitanje o izražajnoj snazi jezika koji opisuju vrijeme.

(9) Nijedan trenutak ne prethodi samome sebi.

(10) Među budućim trenucima, barem jedan najbliži je sadašnjem.

Primjedba 1. Pravi znanstveni jezik samo je onaj jezik kojemu je sintaksa i semantika iskazana eksplicitno te kojemu su ispitana logička svojstva poput izražajne snage, pouzdanosti, potpunosti i odlučivosti. ${ }^{1}$ Sintaksu i semantiku jezika u kojima se govori o vremenu proučava temporalna logika. U temporalnoj modalnoj logici dva elementa, vremenski kvantifikator i glagolsko vrijeme, stapaju se u unarnim rečeničnim operatorima jednom / uvijek - će biti / je bilo (slučaj da). Ako smo vrijeme u jeziku tako shvatili, kao modalitet postojanja, onda se u takvom jeziku nešto može, a nešto ne može opisati, npr. ne može se definirati svojstvo irefleksivnost prethođenja, v. (9). S druge strane, u logici prvog reda vremenski isječci i jedinice promatraju se kao predmeti koje opisujemo odnosima prethođenja i istodobnosti. I ovaj pristup suočen je s ograničenjima u izražajnoj snazi. Na primjer, u jeziku logike prvog reda ne može se iskazati uvjet dobre utemeljenosti (10). Ovakva teorijski izazovna logička pitanja o izražajnoj snazi pojedinog jezika ostavit ćemo po strani. ${ }^{2}$

\subsection{Dvije vrste pojmova}

Tipovi pojmova i definicija. Podijelimo pojmove na generičke (genus, lat. rod) i relacijske (relatio, lat. odnos). Generičkim nazovimo one pojmove koji obuhvaćaju predmete i događaje. Na primjer, 'gibanje'

\footnotetext{
${ }^{1}$ Pojam znanstvenog jezika prvi je sagledao Gottfried Wilhelm Leibniz (1646-1716), filozof i matematičar, Nijemac slavenskih korijena. Znanstveni jezik omogućuje sveopću razumljivost i provjerljivost. Sveopću razumljivost znanstveni jezik postiže zahvaljujući činjenici da je iskazan ideografskim, a ne fonetskim pismom, to nije govorni, nego pisani jezik dogovorene simbolike (lat. characteristica universalis). Provjerljivost znanstveni jezik ima kada je njegova transformacijska iliti logička sintaksa iskazana eksplicitno u računu zaključivanja (lat. calculus ratiocinator). (1999).

${ }^{2}$ Logička svojstva različitih jezika za teorije vremena istražio je Johan van Benthem
} 
je generički (rodni) pojam jer obuhvaća neke vrste događaja. Generičke pojmove često možemo definirati »klasičnim načinom« tako da ih možemo zamijeniti izrazom koji ih definira. Relacijskim nazovimo one pojmove koji obuhvaćaju nizove predmeta i događaja. Na primjer, "prije' je relacijski pojam jer obuhvaća parove događaja. Relacijske pojmove često ne možemo definirati tako da navedemo izraz koji ih može zamijeniti, nego ih »implicitno definiramo« navodeći načela koja vrijede za odnos koji definiramo.

Vrijeme i prosti vremenski poredak. Pojam o vremenu nije generički pojam jer vrijeme ne možemo poistovjetiti s nekom neuređenom zbirkom trenutaka, razdoblja ili događaja. Pojam o vremenu relacijski je pojam koji obuhvaća uređene parove trenutaka, razdoblja ili događaja. ${ }^{3}$ Nazovimo ovako shvaćeno vrijeme 'vremenskim poretkom', a najjednostavniji vremenski poredak ('prosto vrijeme') definirajmo kao združivanje relacijskih pojmova 'prije' i 'istodobno'. Prosto je vrijeme poredak $a R b$ koji se javlja bilo u slučaju prethođenja $a<b$ : $\gg a$ se pojavilo prije $b \ll$, bilo u slučaju istodobnosti $a I b$ : $\gg a$ se pojavilo istodobno s $b \ll$. Svojstva prostog vremenskog poretka su:

1. Prijelaznost (2.1.) i nepovratnost (2.2.) prethođenja. ${ }^{4}$

2. Prijelaznost (2.3.) i povratnost (2.4.) istodobnosti.

3. Odnosi prethođenja i istodobnosti povezani su prema načelu (2.5.) tako da istodobno može biti samo ono što nije u odnosu prethođenja.

$$
\begin{gathered}
(a<b \wedge b<c) \Rightarrow a<c \\
a<b \Rightarrow \neg b<a \\
(a I b \wedge b I c) \Rightarrow a I c \\
a I b \Rightarrow b I a \\
a I b \Rightarrow(\neg a<b \wedge \neg b<a)
\end{gathered}
$$

${ }^{3}$ Slično poimanje vremena nalazimo kod Aristotela u Fizici, 219b: »... vrijeme jest upravo ovo: broj kretanja naprama 'prije i poslije'«.

${ }^{4}$ Prijelaznost je svojstvo odnosa prethođenja prema kojemu za taj odnos vrijedi da: ako je prvo prije drugoga, a drugo prije trećega, onda je prvo prije trećega. Da je odnos prethođenja nepovratan (asimetričan), znači da: ako je prvo prije drugoga, onda drugo nije prije prvoga. 
Slika 2.1. Primjer nesveobuhvatnog poretka: $e$ je izvan prostog vremenskog poretka. Točkasta crta označava istodobnost, a strelica vremensko prethođenje. Veze koje su posljedice tranzitivnosti kod odnosa prethođenja i odnosa istodobnosti nisu ucrtane; jednako kao ni refleksivne veze kod istodobnosti.

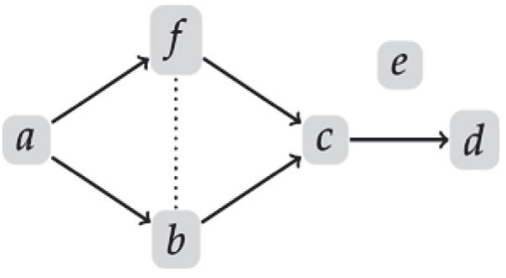

Slika 2.2. Primjer usporednih vremenskih poredaka. $\mathrm{U}$ poretku $R_{1}$ (puna strelica označava prethođenje) vrijedi $a<_{1} b<_{1} c$. U poretku $R_{2}$ (točkasta crta označava istodobnost) slučaj je da $a I_{2} b I_{2} c$. U $R_{3}$ (isprekidana strelica označava prethođenja) vrijedi $c<_{3} b<_{3} a$.

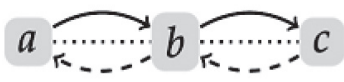

\subsection{Tipovi vremena uz primjere iz povijesti ideja}

Načela (2.1.)-(2.5.) dopuštaju nadogradnju različitim tumačenjima vremenskog poretka. Zanimljiva je činjenica da u povijesti ideja možemo pronaći primjere za tri od četiri tipa interpretacijske nadgradnje koje dobivamo razdiobom dopuštenih tumačenja na osnovi dvaju kriterijskih pitanja:

1. Koliko vremenskih poredaka ima?

2. Obuhvaćaju li vremenski poretci sve događaje?

Poimanje vremena zvat ćemo jedinstvenim ako se njime zahtijeva točno jedan vremenski poredak. Ako se dopušta da vremenskih poredaka ima više, takvo poimanje vremena nazvat ćemo usporednim. ${ }^{5}$ Vrijeme nazivamo sveobuhvatnim akko vremenski poredak obuhvaća sve događaje (2.7.); događaji se nalaze u vremenskom poretku $R$ ako je ili jedan prije drugog ili su oba istodobna (2.6.).

${ }^{5}$ U ovome slučaju, pojam 'vrijeme' postaje generičkim pojmom, koji kao predmete obuhvaća vremenske poretke. 


$$
\begin{gathered}
\forall a \forall b(a R b \Leftrightarrow(a<b \vee b<a \vee a I b)) \\
\forall a \forall b(a R b \vee b R a)
\end{gathered}
$$

U Tablici 2.1. uvodimo četveročlanu tipologiju vremenskih poredaka.

Tablica 2.1. Tipologija pojmova o vremenu s obzirom na pitanje o broju vremenskih poredaka i pitanje njihove obuhvatnosti. Ako se dopušta jedan vremenski poredak, nazivamo ga 'jedinstvenim'; ako dva ili više, 'usporednim'. Za tri tipa primjere pronalazimo kod znamenitih teoretičara, četvrti tip za sada ostavljamo bez primjera.

\begin{tabular}{|l|l|l|}
\hline VRIJEME & Sveobuhvatnost poretka & Nesveobuhvatnost poretka \\
\hline Jedinstveno & $\begin{array}{l}\text { JAKI TEMPORALNI MONIZAM } \\
\text { (Newton) }\end{array}$ & $\begin{array}{l}\text { SLABI TEMPORALNI MONIZAM } \\
(?)\end{array}$ \\
\hline Usporedno & $\begin{array}{l}\text { SLABI TEMPORALNI PLURALIZAM } \\
\text { (Kant) }\end{array}$ & $\begin{array}{l}\text { JAKI TEMPORALNI PLURALIZAM } \\
\text { (Einstein) }\end{array}$ \\
\hline
\end{tabular}

Newton: vrijeme kao apstraktna struktura. Kada Newton piše o vremenu, on ne opisuje poredak događaja, nego protjecanje »apsolutnog« vremena (lat. absolutus, doslovno: oslobođen-a/o), koje teče neovisno o događajima: ${ }^{6}$

»Ne definiram vrijeme, prostor, mjesto i gibanje jer su svima poznati. Tek moram napomenuti da obični ljudi te količine poimaju samo u odnosu na predmete opažanja. Iz takvog poimanja nastaju neke zablude te je, stoga, prikladno razlikovati apsolutne i relativne, prave i prividne, matematičke i pučke [pojmove o tim količinama].

I. Apsolutno, pravo ili matematičko vrijeme, po sebi i iz svoje vlastite prirode, ravnomjerno teče bez odnosa prema ičemu vanjskom, te se drukčije naziva trajanjem. Relativno, prividno ili pučko vrijeme je opažajna i izvanjska [...] mjera trajanja pomoću nekog gibanja, kojim se, umjesto pravim vremenom, obični ljudi koriste, poput sata, dana, mjeseca i godine.« (Newton, [1687] $1846,77)$

Iako Newtonovo apsolutno vrijeme ne ovisi o postojanju stvarnih događaja, izgleda nam nemogućim zamisliti ga bez odnosa prije/pos-

${ }^{6}$ Newtonova knjiga o matematičkim načelima u filozofiji prirode prvi je put objavljena 1687. na latinskom jeziku pod naslovom Philosophiae naturalis principia mathematica. 
lije među njegovim dijelovima. $\mathrm{U}$ vremenu bez događaja vremenski se poredak javlja među trenucima i vremenskim intervalima. Biti dio vremena znači biti smješten unutar vremenskog poretka pa nije moguće za dio vremena da bude izvan vremenskog poretka. Zbog toga Newtonov pojam apsolutnog vremena pored jedinstvenosti poretka uključuje sveobuhvatnost tog poretka (v. Tablica 2.1.).

Kant: vrijeme kao primitivni pojam. Prema Kantu, ništa od onog što ćemo u svijetu opažati ili o njemu misliti nije nam unaprijed zadano, nego je zadan samo način kako ćemo svijet opažati i o njemu misliti. Vrijeme je jedan takav unaprijed zadan način kako ćemo opažati. Kant piše:

»Vrijeme nije iskustveni pojam koji bi nekako proizlazio iz iskustva. Naime, istodobnost i uzastopnost ne bi se javljale u opažanju da im predstavljanje vremena ne daje osnovu a priori. Samo je pod tom pretpostavkom moguće da predočimo sebi da neki predmeti postoje u istome vremenu (istodobno) ili u različitim vremenima (uzastopno).« (Kant, [1787] 1998, 162)

Opažajući svijet oko sebe i svijet u sebi, opažamo poredak koji naše osjete postavlja bilo kao istodobne ili uzastopne, ali taj poredak sâm nije jedan od osjeta. Struktura (oblik) vremenskog poretka omogućuje doživljaj vremena. Pripada li Kantov pojam o vremenu tipu usporednih-sveobuhvatnih poredaka? S obzirom na osjete, vremenski poredak sve ih zahvaća pa je sveobuhvatan. S obzirom na broj vremenskih poredaka, Kantov pojam vremena ne isključuje mogućnost da se za jednog opažajućeg subjekta događaj $a$ pojavi prije događaja $b$, a da se za drugoga $a$ javlja istodobno s $b$ (pod pretpostavkom da nam je dopušteno, što inače u Kantovoj teoriji nije, govoriti o onome na što se sadržaji opažanja odnose). Zato Kantov pojam vremena dopušta postojanje usporedenih vremenskih poredaka. Otvoreno je pitanje predstavlja li sužavanje pojma vremena na vrijeme (ili vremena) opažanja nedopustiv postupak izjednačavanja fizikalnog i psihološkog vremena. ${ }^{7}$ Odgovor je potvrdan ako je moguće da ono što je istodobno u opažanju ne bude istodobno u stvarnosti. Otvara se i pitanje logičkog položaja (relacijskog) pojma o istodobnosti: je li on zaista primitivan pojam, kako se to tvrdi u Kantovom ispitivanju strukturalnih preduvjeta opažanja (naime u transcendentalnoj estetici)?

Razvoj filozofije i znanosti nije preuzeo ni Newtonov ni Kantov pojam o vremenu. Nasuprot Newtonu, odbačene su pretpostavke da postoji

\footnotetext{
${ }^{7}$ Takvo izjednačavanje nedopušteno je ako podražajima treba različito vrijeme da od svog izvora stignu do osjetila ili senzora. Npr. ako se munja vidi prije nego što se grom čuje, to ne znači da se uzrok jednome pojavio prije uzroka drugome.
} 
samo jedan pravi vremenski poredak i da vremenski poredak obuhvaća sve događaje. Nasuprot Kantu, odbačena je pretpostavka o položaju pojma istodobnosti u redoslijedu spoznaje: istodobnost nije početan (primitivan) pojam nego definiran. K tome, nužno je razlikovati stvarni (fizikalni) vremenski poredak od doživljenoga (psihološkoga) poretka.

Einstein: dva vremenska poretka. U specijalnoj teoriji relativnosti (Einstein, 1905) istodobnost prestaje biti primitivan pojam te dobiva status definiranog pojma, ali ne u smislu odgovora na pitanje što je ona, nego kako se istodobnost pronalazi. $\mathrm{U}$ ovoj teoriji vremenski poredak prestaje biti unaprijed zadan okvir, bilo za odvijanje stvarnih događaja (kao kod Newtona), bilo za njihovo opažanje (kao kod Kanta). Istodobnost se pronalazi u nekom okviru događaja ako signal odaslan iz jednog događaja susreće jednako brz signal odaslan iz drugog događaja na polovini njihove udaljenosti. ${ }^{8}$ Sada pojam brzine dolazi na početak definicijskog niza dok jednakost brzina (signala) postaje presupozicijom istodobnosti, njezin uvjet mogućnosti. Ovakva definicija kao da zapada u začarani krug (lat. circulus vitiosus) jer brzina je odnos duljine puta i njegova trajanja, trajanje je mjera vremena, vrijeme je poredak događaja na osnovi prethođenja i istodobnosti, a istodobnost je operacijski definirana pod pretpostavkom jednakosti brzina. Zato, prema prigovoru, definiens pojma istodobnosti uključuje pojam istodobnosti. Einstein dovodi u pitanje metodološku smislenost tog prigovora s obzirom na empirijske znanosti u kojima se javljaju operacijske definicije; potpada li nešto pod definiendum određuje se radnjom provjeravanja koja uključuje osvrtanje na iskustvenu pojavu:

»To da svjetlost zahtijeva neko vrijeme za prijeći put $A \rightarrow M$, kao i za put $B \rightarrow M$, zapravo nije pretpostavka ni hipoteza o fizikalnoj prirodi svjetlosti, nego uvjet kojega sam slobodan postaviti kako bih došao do definicije istodobnosti. «9 (Einstein [1916] 2005, 31-32)

Einsteinova definicija istodobnosti ne isključuje mogućnost da isti par događaja stoji u različitim vremenskim odnosima unutar različitih okvira odredbe (fizikalno, unutar različitih inercijskih okvira).

Drukčiji pojam o vremenskom poretku dobivamo kada o vremenu razmišljamo kroz mogućnosti utjecaja: ' $a$ je istodoban ili raniji od $b$ ' neka sada

\footnotetext{
${ }^{8}$ Nataša Rakić $(1997,6)$ daje sljedeću definiciju: »Dva događaja $e_{1}$ i $e_{2}$, koji se javljaju na točkama $p_{1}$ i $p_{2}$ unutar inercijskog okvira $F$, istodobna su $u F$ ako i samo ako svjetlost odaslana iz $e_{1}$ susreće svjetlost odaslanu iz $e_{2}$ u točki koja se nalazi u sredini segmenta $p_{1} p_{2} \mathrm{u} F$.《

${ }^{9} M$ je točka na polovini puta $A B$.
} 
znači ' $a$ može utjecati na $b$ ' ${ }^{10}$ Svaki događaj ima svoju jedinstvenu uzročnu budućnost (ono na što on može utjecati) i jedinstvenu prošlost (ono što na njega može utjecati). Prema specijalnoj teoriji relativnosti brzina djelovanja ne može imati bilo koju veličinu, nego samo neku od onih koje nisu veće od brzine svjetlosti. Ako bi signal odaslan iz jednog događaja mogao dosegnuti drugi događaj samo ako bi putovao brzinom većom od brzine svjetlosti, onda niti prvi događaj može utjecati na drugi niti drugi na prvi. Takvi su događaji jedan prema drugom u »uzročnoj onostranosti« (v. Slika 2.3.).

Jaki temporalni pluralizam: usporednost $i$ nesveobuhvatnost. Oba pojma o vremenu iz specijalne teorije relativnosti dopuštaju usporednost vremenskih poredaka. Vremenski poredak iz prve, neuzročne definicije nije jedinstven: koliko okvira promatranja - toliko vremenskih poredaka. Vremenski poredak iz druge, uzročne definicije također nije jedinstven jer dopušta uzročnu onostranost. Zbog toga on nije ni sveobuhvatan.

Slika 2.3. Dodajmo zvjezdicu na kraju riječi da bismo označili pojam o vremenu kao mogućnosti utjecaja. Dijagram uzročnu budućnost* neke točke prikazuje kao gornji dio ravnine omeđene crtama koje izlaze iz te točke, dok je prošlost* donji dio ravnine između crta koje ulaze $u$ tu točku. Nemogućnost utjecaja između $a$ i $b$ prikazuje se time što se jedna točka ne javlja ni u budućnosti* ni u prošlosti* druge.

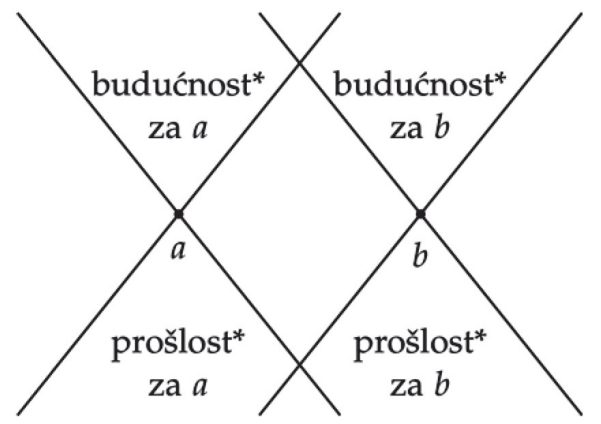

${ }^{10}$ N. Rakić (1997, 16-17) definira pojam o mogućnosti utjecaja unutar specijalne teorije relativnosti (STR) na sljedeći način: »Događaj $e_{1}$ je STR-apsolutno bilo istodoban ili raniji od događaja $e_{2}\left(e_{1} \leq e_{2}\right)$ akko signal odaslan iz $e_{1}$ može dosegnuti $e_{2}$. [...] STR uzročni odnos dijeli sve događaje na tri različita razreda s obzirom na neki događaj e. [...] prvi razred obuhvaća događaje na koje $e$ može utjecati, drugi one koji mogu utjecati na $e$. Budući da brzina svjetlosti postavlja granicu na mogućnost povezivanja događaja putem signala, time postavlja granicu na mogućnost utjecaja kada se neki događaji ne mogu povezati putem signala. Stoga, treći razred događaja obuhvaća one koji niti mogu uzročno utjecati na $e$ niti $e$ može utjecati na njih.« 


\subsection{Vrijeme opažanja i vremena mišljenja}

Vremenski poredak u kojega se smještaju podatci promatranja nazovimo opažajnim vremenskim poretkom. Kod zaključivanja oslanjamo se na pojam, najčešće nesvjesno, o nekom ili nekim vremenskim poretcima. Moraju li se slagati dvije vrste vremenskih struktura, ona u opažanju i ona u mišljenju? Negativan odgovor na to pitanje svoj je dokaz dobio činjeničnim putem. Da takav nesklad postoji, pokazao je Jean Piaget (1896-1980), teorijski i eksperimentalni istraživač znanja (epistemolog), otkrivši da dijete na pitanje o tome jesu li istodobna dva događaja koja je ono upravo zapazilo kao istodobne ponekad može odgovoriti $N e$, upravo zbog unutarnje neusklađenosti vremenskog poretka opažanja i vremenskog poretka zaključivanja. ${ }^{11}$ Perceptivno-kognitivni konflikt i njegova uloga u dinamici znanja tek se trebaju logički opisati $i$ ispitati. Naša je tema vezana uz raznolikost teorija o vremenskom poretku pa se vraćamo preostalom tipu (slabog monizma), vremenskom poretku koji je jedinstven ali nije sveobuhvatan.

Kantova hipoteza o nužnosti načina kako opažamo i mislimo o vremenskom poretku mogla bi se spasiti ako bi se pokazalo da je istodobnost psihološki nužan oblik opažanja kad već nije primitivan pojam fizikalne teorije. Pitanje o zatečenom (primitivnom) ili stečenom (derivativnom) položaju vremenskog uređenja opažanja ne može se drukčije ispitati nego empirijski. Na Međunarodnom kongresu filozofije i psihologije u Davosu (Švicarska) 1928. godine Albert Einstein predložio je Jeanu Piagetu neka ispita kod djece podrijetlo pojma o vremenu, a posebno pojma o istodobnosti. Piagetova, protukantovska i ajnštajnovska, hipoteza, da u razvoju mišljenja pojam brzine prethodi pojmu o istodobnosti, pokazala se konzistentnom u odnosu na eksperimentalna zapažanja.

Primjer. U jednom od Piagetovih eksperimenta za ispitivanje razvoja pojma istodobnosti eksperimentator u ruci drži dvije lutke jednu pored druge te ih pokreće i zaustavlja po zapovijedima djeteta u dvjema eksperimentalnim situacijama $A$ i $B$. Kada dijete kaže Kreni, eksperimentator pokreće lutke u isto vrijeme. U eksperimentalnoj situaciji $A$ lutke se gibaju jednakom brzinom i kada dijete kaže Stani, one se zaustavljaju jedna pored druge jer su prevalile jednake putove. U eksperimentalnoj situaciji $B$ jedna od lutaka kreće se većim skokovima nego druga pa kad dijete kaže Stani, jedna je odmakla dalje nego druga. Eksperimentator postavlja sljedeća pitanja: [?Start] Jesu li lutke krenule u

${ }^{11}$ Knjigu - znanstveni izvještaj - o dječjem poimanju vremena Piaget je objavio 1946. 
isto vrijeme, [?Stop] Jesu li se lutke zaustavile u isto vrijeme. Iznenađujući rezultat, prikazan na Tablici 2.2., sastoji se u tome što dijete odbija prihvatiti istodobnost zaustavljanja dviju lutaka u situaciji $B$.

Tablica 2.2. Piagetov eksperiment

\begin{tabular}{|l|c|c|}
\hline & ?Start & ?Stop \\
\hline Dječji odgovor u situaciji $A$ & DA & DA \\
\hline Dječji odgovor u situaciji $B$ & DA & $\mathrm{NE}$ \\
\hline
\end{tabular}

Piaget ovako tumači rezultate eksperimenta:

»Pojam o istodobnosti - dvije stvari koje se događaju u isto vrijeme - jednostavno nema smisla za djecu kada se odnosi na kvalitativno različita gibanja. Taj pojam ima smisla kada se odnosi na kvalitativno slična gibanja kojima je brzina jednaka, kao u situaciji $A$, ali kada se radi o različitim vrstama gibanja [kao u situaciji $B$ ], on za njih jednostavno nema smisla. Ne postoji primitivna intuicija istodobnosti [...] Pojam istodobnosti zahtijeva intelektualnu konstrukciju.« (Piaget, 1971, 71)

U dječjoj teoriji vremena moguće je da neki događaji ne budu vremenski povezani ili, drukčije rečeno, u toj teoriji vremenski poredak nije sveobuhvatan. Iako u situaciji $B$ dijete opaža istodobnost dvaju događaja zaustavljanja, njegov pojam istodobnosti ne obuhvaća slučaj kada se istodobno zaustavljaju predmeti koje je vidjelo da su se gibali različitim brzinama. Našu tipologiju sada možemo upotpuniti primjerom za četvrti tip vremenskog poretka i neka to bude jedno od djece koja su sudjelovala u eksperimentu - sedmogodišnji dječak Arl (Piaget, 1977, 555) (v. Tablicu 2.3.).

Tablica 2.3. Upotpunjena tipologija vremenskih poredaka. Nedostajući tip, jedinstveno ali nesveobuhvatno vrijeme, nalazi se u dječjem pojmu vremena.

\begin{tabular}{|l|l|l|}
\hline VRIJEME & Sveobuhvatnost poretka & Nesveobuhvatnost poretka \\
\hline Jedinstveno & $\begin{array}{l}\text { JAKI TEMPORALNI MONIZAM } \\
\text { (Newton) }\end{array}$ & $\begin{array}{l}\text { SLABI TEMPORALNI MONIZAM } \\
\text { (Arl, 7 god.) }\end{array}$ \\
\hline Usporedno & $\begin{array}{l}\text { SLABI TEMPORALNI PLURALIZAM } \\
\text { (Kant) }\end{array}$ & $\begin{array}{l}\text { JAKI TEMPORALNI PLURALIZAM } \\
\text { (Einstein) }\end{array}$ \\
\hline
\end{tabular}




\subsection{Anomalija u razvoju pojma vremena}

Povežimo dvije teorije: s jedne strane, Einsteinovu teoriju fizikalnog vremena, prema kojoj se vremenski poredak konstruira na osnovi ispitivanja istodobnosti događaja, a potvrđivanje istodobnosti pretpostavlja, između ostalog, jednakost brzine iz njih odaslanih signala i, s druge strane, Piagetovu teoriju o epistemološkom razvoju pojma vremena, prema kojoj postoji niža razina epistemološkog razvoja na kojoj ne postoji intuicija istodobnosti pa ona zato nije primitivan, nego konstruiran pojam. Suočavamo se s paradoksalnim rezultatom: napredak u znanstvenome mišljenju kao da zahtijeva vraćanje unatrag od višeg stupnja (gdje se brzina poima pomoću vremena) na niži razvojni stupanj mišljenja (gdje se vrijeme poima pomoću brzine). Paradoks je samo prividan. Prvo, čini se da logička struktura pojma vremena kakva se javlja na najvišem stupnju individualnog razvoja mišljenja ne mora samim time biti jednaka logičkoj strukturi pojma vremena u najvišem stupnju znanstvenog mišljenja. Drugo, dvije teorije o vremenu, jaki temporalni pluralizam i slabi temporalni monizam, slične su po tome što $u$ njima istodobnost nije primitivan pojam, ali njihove su razlike toliko velike da ih čine neusporedivim. Za razliku od teorije vremena u specijalnoj teoriji relativnosti, dječja teorija pati od nekonzistentnosti. ${ }^{12}$ Radije, pouka koju možemo pronaći u povijesti pojma u vremenu jest ta da znanstveno mišljenje zahtijeva takvu otvorenost mišljenja u kojoj reviziji podliježe čak i ono što nam se, na dosegnutom stupnju razvoja našeg individualnog mišljenja, čini intuitivno jasnim i nesumnjivim.

\section{Vrijeme i obrazovanje za otvorenost: kratki osvrt}

Povijest pojma o vremenu dokazuje uzaludnost očekivanja Moderne da mora postojati povlašteni, nepromjenljivi, intuitivni dio ljudskoga znanja, pa makar taj dio bio skromno sužen na sam oblik znanja. Jed-

12 Jedan od Piagetovih eksperimenata pokazuje nekonzistentnost dječje teorije. Neka žuti predmet započinje gibanje u točki $A$ u trenutku $t$ i neka se giba stazom $A B$. Drugi, plavi predmet započinje gibanje u točki $C$ poravnatoj s $A$ u istom trenutku $t$ stazom $C D$ koja je duža od $A B$. Oba predmeta zaustavljaju se u istom trenutku $t$ ' $:$ žuti na točci $B$, a plavi na točci $D$. Dijete poriče istodobnost zaustavljanja. No, kada se eksperiment provede unatrag tako da početne točke budu $B$ i $D$, a točke zaustavljanja budu $A$ i $C$, tada dijete ne poriče, nego potvrđuje istodobnost zaustavljanja. 
nako tako, ta nam povijest razotkriva metodološki neuspjeh modernističkog projekta parcelacije znanja iscrtavanjem disciplinarnih granica: teorija vremena ne može se izgraditi u izoliranoj disciplini. Piagetov pristup, jasno istaknut u nazivu 'razvojna epistemologija', pokazuje da se u istraživanju znanja ne smije postaviti međa koja bi rastavila pitanje podrijetla znanja (razvojna ...) od pitanja njegove valjanosti (... epistemologija).

Analiza povijesti pojma vremena rasvijetlila je dvije strane otvorenosti znanja, onu deskriptivnu i onu normativnu. U deskriptivnom smislu, znanje je otvoreno jer se mijenja, i to ne samo s obzirom na sadržaj koji mu se dodaje ili uklanja iz njega, nego i s obzirom na svoj oblik (okvir, strukturu, paradigmu). Naša je analiza pokazala da promjene u pojmu vremena ne uključuju samo prihvaćanje ili odbacivanje jedinstvenosti i sveobuhvatnosti vremenskog poretka, nego se također mijenja unutarnja logička struktura pojma. U potonjoj vrsti promjene, vidjeli smo na primjeru logičkog položaja pojma istodobnosti, nema čvrstih točaka u razvoju znanja: ono što je u jednoj etapi jasno po sebi, može ne biti takvo na ranijoj i može prestati biti takvo na kasnijoj etapi procesa znanja. U normativnom smislu, znanje ne treba cijepati u čestice. Pojam vremena, koji podjednako prožima povijesne i prirodne znanosti, element je znanja koji se ne može zatvoriti u okvir jedne čestice jer kada bi se to dogodilo, sve bi ostale čestice empirijskog znanja prestale postojati.

Potražimo pedagoške posljedice ovog analitičkog istraživanja o pojmu vremena. Učitelj je nužno suočen sa svojom samosvijesti, vlastitim pitanjem o vlastitoj djelatnosti. Ili, govoreći novijim rječnikom: edukacija je refleksivna praksa. Na takvo pitanje odgovor možemo dati jedino mi sami. Novijim rječnikom kazano: edukacija uključuje profesionalnu autonomiju. Prema tome, učiteljstvo uključuje oboje, i refleksivnu praksu i profesionalnu autonomiju jer se u refleksiji suočava s vlastitim pitanjem o vlastitoj praksi na koje treba zbog autonomije dati vlastiti odgovor. Autonoman odgovor na refleksivno pitanje o smislu učiteljstva nije proizvoljan odgovor niti odgovor koji nam je nužno jasan po sebi. Radije, to je odgovor o kojem treba dobro promisliti i kritički ga preispitati. Taj odgovor trebamo tražiti oslanjajući se na najbolje znanje koje pronalazimo u uvidima edukacijske filozofije i znanosti te u vlastitom iskustvu i kolegijalnom dijalogu. Takav odgovor iskazuje našu edukacijsku filozofiju. Kojoj edukacijskoj filozofiji mo- 
žemo konzistentno dodati filozofskoznanstveni uvid da logička stuktura znanstvenog pojma vremena ima svojstvo kojega ne nalazimo u implicitnom pojmu vremena na psihološkom stadiju intelektualne zrelosti?

Ako je obrazovanje put prema znanju a znanje je otvoreno, kako primjer pojmovnih promjena o vremenu pokazuje, onda je otvorenost cilj obrazovanja. Sličan stav pronalazimo u epohi Prosvjetiteljstva gdje je obrazovanjem (njem. Bildung) nazvan put do zrelosti slobodne samostalne ličnosti. Zrelost je otvorenost: zrelost nadilazi puku određenost vlastitim društvenim položajem, ali ne putem stjecanja posjeda nad konačnim istinama, nego kroz otvorenost za drugog i drukčije. ${ }^{13}$ Povijest pojma vremena pokazuje da se kod Einsteina zrelost znanstvenog mišljenja otkrila u otvorenosti prema onoj logičkoj strukturi koja u manjoj mjeri odgovara zreloj nego dječjoj implicitnoj teoriji. Ako u otvorenosti pronalazimo odgovor na pitanje o tome prema kojoj je vrijednosti usmjereno naše učiteljsko djelovanje, onda takav odgovor nalazi potkrjepljenje u zanimljivoj divergenciji između psihološkog razvoja i znanstvenog napretka s obzirom na logičku strukturu pojma vremena. Zbog toga složeni fenomen obrazovanja za otvorenost zavrjeđuje punu pažnju u znanosti i obrazovanju. ${ }^{14}$

\section{Literatura}

Aristotel (1988), Fizika, Zagreb: Sveučilišna naklada Liber.

Basariček, Stjepan (1903), Pedagogija: II. dio: Obća nauka o obuci, Zagreb: Hrvatski pedagogijsko-književni zbor.

Benthem, J. van (1999), »Temporal patterns and modal structure«, Logic Journal of the IGPL 7(1), str. 7-26. http://dx.doi.org/10.1093/jigpal/7.1.7

Einstein, Albert (2005), Relativity: The Special and the General Theory, New York: Pearson Education. http://dx.doi.org/10.1515/9781400865666

Gadamer, Hans Georg (2004), Truth and Method, London: Continuum.

Kant, Immanuel (1998), The Critique of Pure Reason, Cambridge: Cambridge University Press. http://dx.doi.org/10.1017/cbo9780511804649

${ }^{13}$ Gadamer ([1960] 2004, 15-16) ovako tumači prosvjetiteljski pojam zrelosti: »Univerzalna stajališta prema kojima zreo čovjek ostaje otvoren nisu neka čvrsto utvrđena mjerila, nego su mu ona dana kao stajališta mogućih drugih."

${ }^{14}$ Michael Peters (2010) suvremeni obrazovni smisao otvorenosti opisuje riječima: »Otvoreno obrazovanje i obrazovanje za otvorenost povezani su projekti i oni izgleda da tvore jedno od najvažnijih gibanja u obrazovanju koje se pomalja u dvadeset prvom stoljeću.« 
Newton, Isaac (1846), The Mathematical Principles of Natural Philosophy, New York: Daniel Adee.

Peters, Michael A. (2010), »The idea of openness «, u: Peters, Michael A.; Gibbons, Andrew; Besley, Tina; Žarnić, Berislav i Ghiraldelli, Paulo (ur.), Encyclopaedia of Educational Philosophy and Theory. Dostupno na: http://eepat.net/doku.php?id=the_idea_of_openness

Piaget, Jean (1971), Genetic Epistemology, New York: W. W. Norton \& Company.

Piaget, Jean (1977), »The child's conception of time«, u: Gruber, Howard E. i Vonèche, Jacques J. (ur.), The Essential Piaget, New York: Basic Books.

Rakić, Nataša (1997), Common Sense Time and Special Relativity, Amsterdam: Institute for Logic, Language and Computation.

Žarnić, Berislav (2001), »Learning to learn: An epistemological paradox in education«, Synthesis philosophica 16(2), str. 355-362.

\section{TIME OF OPEN KNOWLEDE}

\section{Berislav Žarnić}

In this paper the minimal theory of temporal order has been defined and axiomatically presented. The concept of time captured by the minimal theory has been termed 'basic time'. The concept of basic time has been divided into four types with respect to criteria of uniqueness and totality of temporal order. The exemplar scientific concepts corresponding to the three of four types have been found in the history of ideas (Newton, Kant, Einstein) and classified (strong temporal monism, weak temporal pluralism, strong temporal pluralism). The fourth, missing exemplar for weak temporal monism has been found in the child's conception of time discovered by Piaget. The analysis of the historical development of the concept of time has revealed that there is an element in its structure that changes its logical status from being defined to being primitive and back to being defined. This anomalous phenomenon regards the logical status of the relation of simultaneity and it brings to light the discontinuity of the logical structure in concept development thus corroborating the dynamic theory of knowledge. Relying on our previous research (Žarnić, 2001) and the recent discovery of systematic theoretical power of the concept of openness (Peters, 2010) we have sketched some traits of the education for openness that are consistent both with the noted anomaly in the conceptual development and with the Enlightenment concept of Bildung.

Key words: temporal logic, education for openness, Jean Piaget, conceptual change, typology of temporal orders 